\title{
Proximal tibiofibular synostosis
}

\author{
Proksimal tibiofibuler sinostoz
}

\author{
Ahmet Yiğit Kaptan, MD., O. Şahap Atik, MD. \\ Department of Orthopedics and Traumatology, Medical Faculty of Gazi University, Ankara, Turkey
}

\begin{abstract}
A 22-year-old male patient admitted to our clinic with mild pain in left knee. Pain had started 10 years ago and there was no history of trauma. Pain was increased with kneeling. No abnormality was detected on physical examination. Imaging results revealed proximal tibiofibular synostosis in left knee.

Keywords: Proximal; synostosis; tibiofibular.
\end{abstract}

Synostosis of the proximal tibiofibular joint has been described in all age groups secondary to osteochondroma, knee valgus and other syndromes. $\mathrm{O}^{\prime}$ Dwyer ${ }^{[1]}$ classified proximal tibiofibular synostosis into three types. All types included deformities like valgus deformity of the knee, distal positioning of the tibiofibular joint, and leg length discrepancy. Proximal tibiofibular synostosis without multiple hereditary exostosis is extremely rare. ${ }^{[2-4]}$ In this article, we reported a case of proximal tibiofibular joint synostosis with mild knee pain. ${ }^{[5]}$

\section{CASE REPORT}

A 22-year-old male patient admitted to our outpatient clinic suffering from mild pain in left knee. There was no history of trauma. Pain was increased with kneeling. However, passive and active range of motion was within normal limits. There was no crepitation or numbness. Radiogram revealed proximal tibiofibular synostosis (Figure 1a, b). Computed tomography showed synostosis in the proximal tibiofibular joint (Figure 2). The patient was advised surgical treatment but he preferred

\section{$\ddot{O} Z$}

Yirmi iki yaşında bir erkek hasta sol dizde hafif ağrı ile kliniğimize başvurdu. Ağrı 10 yıl önce başlamıştı ve travma öyküsü yoktu. Ağrı diz çökünce artıyordu. Fizik muayenede anormallik tespit edilmedi. Görüntüleme sonuçları sol dizde proksimal tibiofibuler sinostozis gösterdi.

Anahtar sözcükler: Proksimal; sinostoz; tibiofibuler.

lifestyle modification. A written informed consent was obtained from the patient.

\section{DISCUSSION}

Synostosis has been reported at three levels between tibia and fibula. Distal tibiofibular joint synostosis is usually associated with trauma and it is the late complication of surgically treated ankle fractures. ${ }^{[6]}$ Middle tibiofibular joint is formed by interosseous membrane and this joint is between proximal and distal tibiofibular joints. Synostosis of the middle tibiofibular joint is also associated with trauma. ${ }^{[7]}$

Proximal tibiofibular joint synostosis has also been reported in the literature. Growth deformities, exostoses, generalized syndromes, chromosomal anomalies and valgus deformities are associated factors for proximal tibiofibular joint synostoses reported in the literature. ${ }^{[8,9]}$

However, symptomatic idiopathic proximal tibiofibular synostosis has been rarely reported in the literature. ${ }^{[2,3]}$ Sferopoulos ${ }^{[4]}$ investigated proximal tibiofibular joint synostosis among 1,029 patients

- Received: July 21, 2016 Accepted: October 18, 2016

- Correspondence: O. Şahap Atik, MD. Gazi Üniversitesi Tıp Fakültesi Ortopedi ve Travmatoloji Anabilim Dalı, 06500 Beşevler, Ankara, Turkey. Tel: +90 312 - 2025528 e-mail: satikmd@gmail.com 


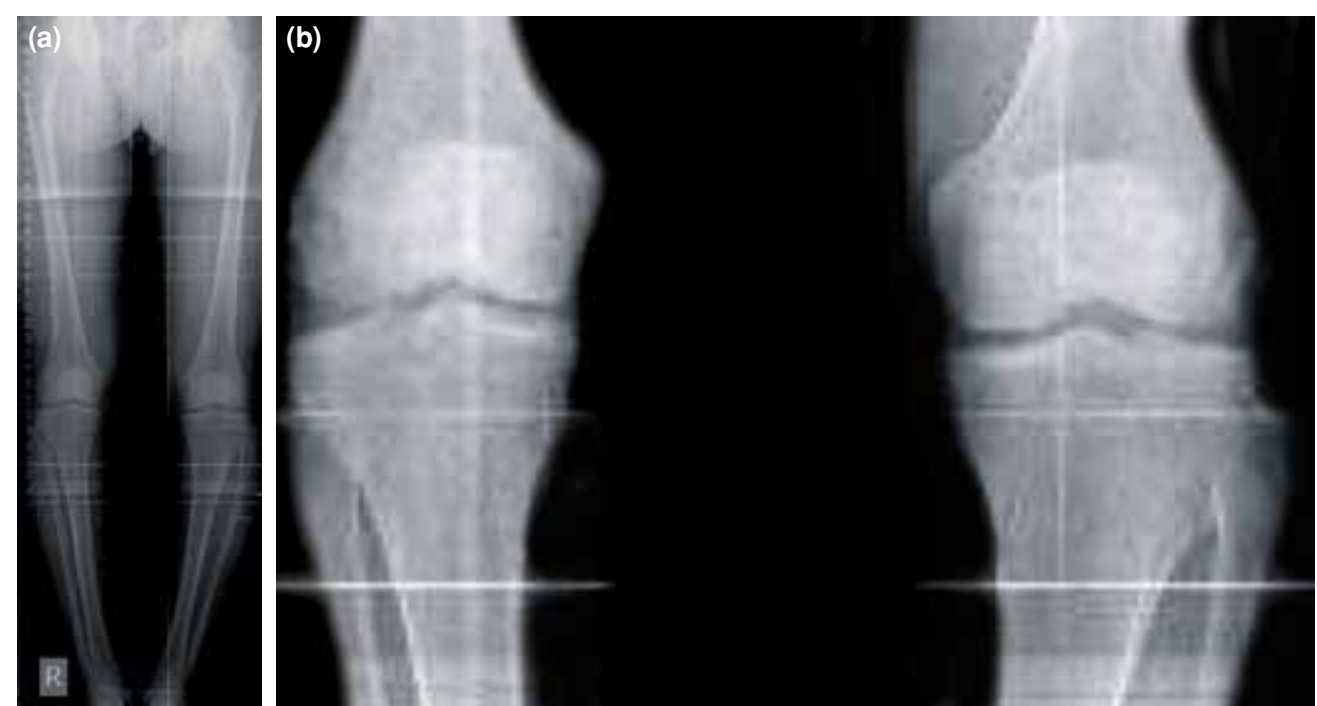

Figure 1. (a, b) Radiographs showing synostosis in the left proximal tibiofibular joint.

examined for osteoarthritis of the knee. There were three patients radiologically diagnosed as proximal tibiofibular joint synostosis. Two of the patients were idiopathic and the other patient had surgical treatment for lateral plateau fracture. However, these patients were not symptomatic.

Lateral knee pain, ankle pain, peroneal nerve palsy and pseudoradicular syndrome have been reported as symptoms of proximal tibiofibular joint synostosis in the literature. ${ }^{[10]}$ Authors hypothesized that synostosis could cause dorsal root activation by stretching the peroneal nerve. However, our patient only had mild knee pain increased with kneeling.

Idiopathic proximal tibiofibular joint synostosis is a rare condition and a variety of symptoms can be found in a patient. Patient's symptoms and physical examination and radiogram findings are diagnostic for the disease.

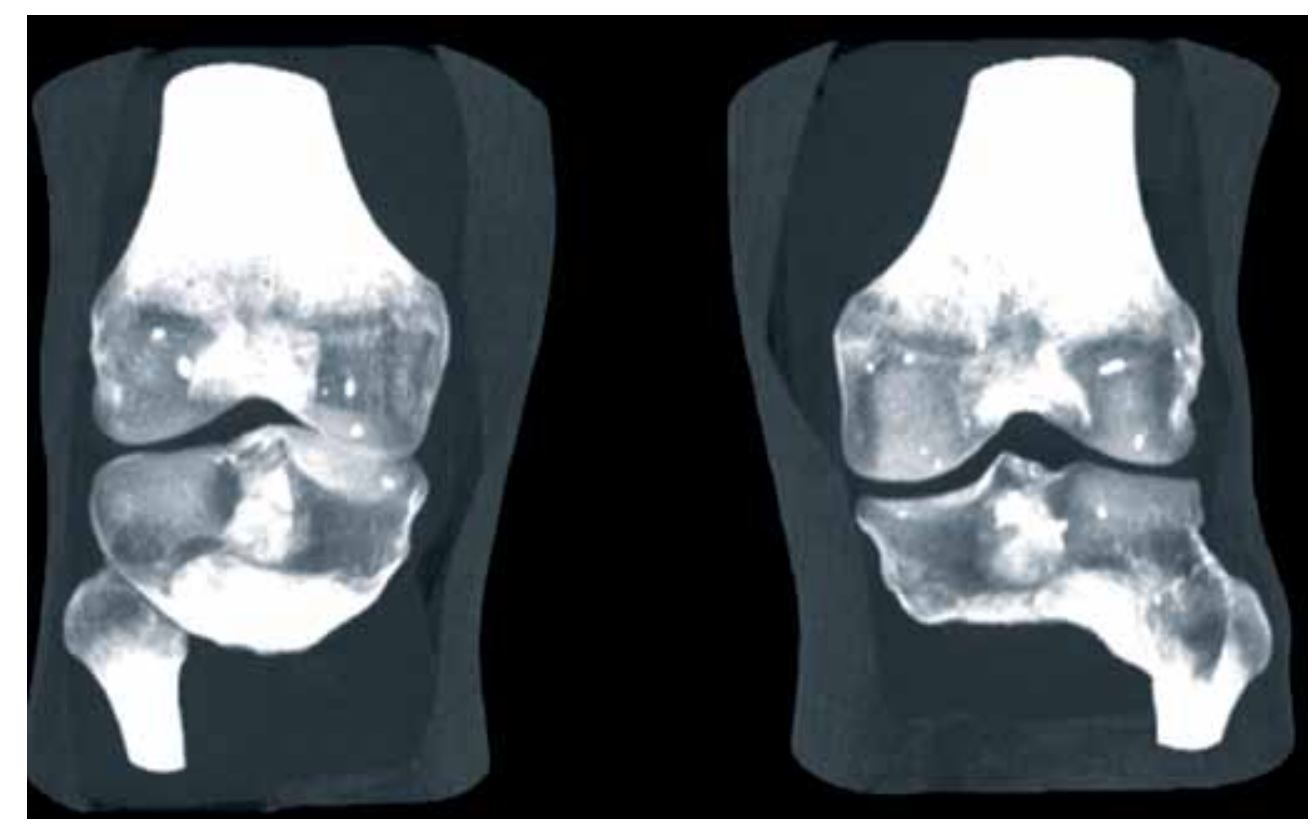

Figure 2. Computed tomography showing synostosis in the left proximal tibiofibular joint. 


\section{Declaration of conflicting interests}

The authors declared no conflicts of interest with respect to the authorship and/or publication of this article.

\section{Funding}

The authors received no financial support for the research and/or authorship of this article.

\section{REFERENCES}

1. O'Dwyer KJ. Proximal tibio-fibular synostosis. A rare congenital anomaly. Acta Orthop Belg 1991;57:204-8.

2. Takai S, Yoshino N, Hirasawa Y. Unusual proximal tibiofibular synostosis. Int Orthop 1999;23:363-5.

3. Kuroiwa $\mathrm{Y}$, Nishikawa A, Imazawa T, Kitamura $\mathrm{Y}$, Kanki K, Ishii Y, et al. A subchronic toxicity study of dunaliella carotene in F344 rats. Food Chem Toxicol 2006;44:138-45.

4. Sferopoulos NK. Synostosis of the proximal tibiofibular joint. Case Rep Med 2010;2010:794594.

5. Atik OŞ. Are all case reports worth publishing? Eklem Hastalik Cerrahisi 2016;27:61.

6. Lenin Babu V, Shenbaga N, Komarasamy B, Paul A. Proximal tibiofibular synostosis as a source of ankle pain: a case report. Iowa Orthop J 2006;26:127-9.

7. Fu JH, Hwang CC, Chao TH. Tibiofibular synostosis in a military soldier. J Med Sci 2003;23:135-8.

8. Bessler W, Eich G, Stuckmann G, Zollikofer C. Kissing osteochondromata leading to synostoses. Eur Radiol 1997;7:480-5.

9. Nishimura T, Nii E, Urawa M, Nishiyama M, Taki S, Uchida A. Proximal tibiofibular synostosis with 49,XXXXY syndrome, a rare congenital bone anomaly. J Orthop Sci 2008;13:390-5.

10. van Ooij B, van Ooij A, Morrenhof JW, van Dijk CN. Proximal tibiofibular synostosis as a possible cause of a pseudoradicular syndrome: a case report. Knee Surg Sports Traumatol Arthrosc 2011;19:2115-8. 